Goldschmidt 2021 Abstract

https://doi.org/10.7185/gold2021.5596

\section{Stages of formation of Rudny Altai in the pre-Devonian}

\section{OLEG M. GRINEV, ALEXEY SEMIRYAKOV, KSENIA V. BESTEMIANOVA AND ROMAN O. GRINEV}

Tomsk State University

Presenting Author: alexey.semiryakov@mail.ru

It is generally accepted that the formation of the Rudny (Ore) Altai megatrough has begun in the Silurian with the accumulation of slope sediments (Korbalikha sequence). These sediments have been crumpled and metamorphosed, and now they form the Aley basement block within the northeastern part of the Rudny Altai. These rocks unconformably underlie the Devonian volcano-sedimentary formation. One can trace magmatic processes of the past by studying detrital zircons, which these rocks contain.

In the Laboratory of Geochronology and Geodynamics of TSU, the LA-Q-ICP-MS method has been used for isotopic and geochemical studies of the detrital zircons.

Figure 1. Wetherill concordia plot for zircons from greenschists of the Aley block, Zmeinogorsk ore district, Rudny Altai

There are two populations of zircons formed in Middle Cambrian ( 496 Ma) and Late Riphean ( $809 \mathrm{Ma})$. Also there are poorly represented Early Riphean, Early Proterozoic and even Late Archean zircons, which is important for understanding the Precambrian history of the entire Altai region.

Most likely Gorny Altai objects had been the sources of detrital zircons in greenschists after the Middle Cambrian. According to the modern knowledge of Altai geodynamics, the two main peaks of zircon accumulation correspond to the oceanic stage $\left(R_{3}-\epsilon_{1}\right)$ and the island arc stage $\left(\epsilon_{1}-O_{1}\right)$ [1]. More ancient boundaries of crust formation and transformation are not taken into account, although they are reflected in the detrital zircon age distribution too.

Thus, both Rudny Altai and Gorny Altai are characterized by long-lasting stages of pre-Hercynian formation, including the Late Archean, Early Karelian, Late Karelian, Baikalian and Caledonian stages.

Funding: The study was funded by RFBR according to the research project № 20-35-90036; was also been supported by Russian Mega-Grant № 14.Y26.31.0012; was also carried out at the expense of the State Task of the Ministry of Science and Higher Education of the Russian Federation, project № 07212020-0041.

[1] Turkin, Fedak (2008) Geology and structural-material complexes of Gorny Altai, pp. 459 (In Russian).

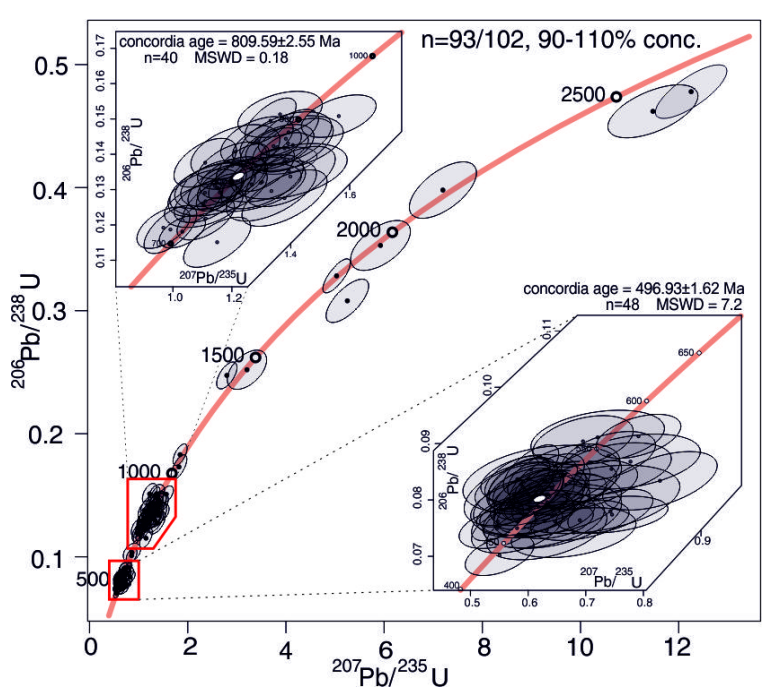

